\title{
Inclusion of absorption heat pumps into heat power plant scheme for stage heating efficiency increase of delivery water
}

\author{
Olga Romashova ${ }^{1, *}$, Dmitrij Luzhkovoj ${ }^{1}$, Aleksandr Tubolev $^{1}$, and Marina Vagner $^{1}$ \\ ${ }^{1}$ National Research Tomsk Polytechnic University, 634050 Tomsk, Russia
}

\begin{abstract}
Design analysis of absorption heat pumps use for delivery water stage heating levelling-off at ambient air temperature decrease has been reported in the present paper.
\end{abstract}

\section{Introduction}

Two stage heating of delivery water at heat power plant in comparison with one stage heating allows to increase electric energy generation at heat consumption. In modern heating turbines there is no opportunity to maintain equal distribution of delivery water heating within the whole heating season, which leads to decrease of efficiency of heating generation of electric energy [1].

Design research of work modes in two stage network installation in turbines of type T110-130 and T-250-240 in respect to climate conditions in Tomsk for temperature chart of heat supply system $150 / 70$ and extraction ratio=0.6 [2] shows that dispatch of heat enormously depends on ambient air temperature. During turbine plants work on heat graph share of water heating in low heating of water in lower line heater at decrease of ambient air temperature increases from (30-40) \% to (65-75) \% with corresponding decrease of heating in upper heater (fig. 1). All other conditions being equal inequality of network heating increases with decrease of delivery water discharge rate and increase of its temperature in return line [3].

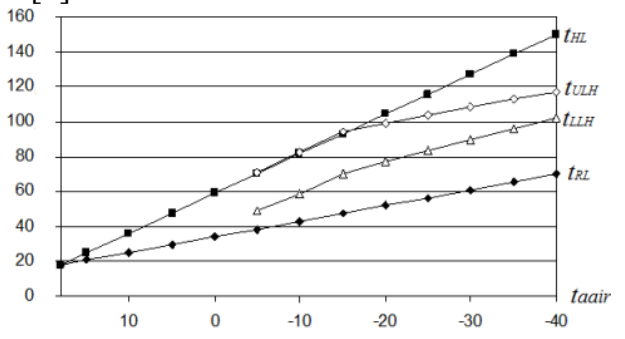

Fig. 1. Temperature chart of heat supply system (HL - heating line, RL - return line, ULH - upper line heater, LLH - lower line heater, aair - ambient air).

\footnotetext{
* Corresponding author: roma@tpu.ru
} 


\section{Statement of problem and limitations}

Variant of absorption heat pumps (AHP) use for delivery water stage heating levelling-off at ambient air temperature decrease has been considered in the present paper [4]. Inclusion of absorption heat pumps into delivery water two stage heating scheme at heat power plant has been presented in fig. 2 . In evaporator of absorption heat pumps return wire temperature decreases due to use of heat of high-potential vapor extraction from turbine. Transmission of heat to delivery water in condenser of absorption heat pumps leads to decrease of delivery water temperature for upper line heater with corresponding decrease of vapor pressure in the upper controlled selection.

Simultaneous decrease of return wire temperature and vapor pressure in upper line heater causes redistribution of heating between upper and lower heaters and allows to approximate work mode of network installation to design mode with equal heating of delivery water. Pressure in work selection and its corresponding delivery water temperature for lower line heater are set on the base of coordinated solution of the Stodola-Flugel formula for interstage section of turbine and heat-balance equation of lower line heater.

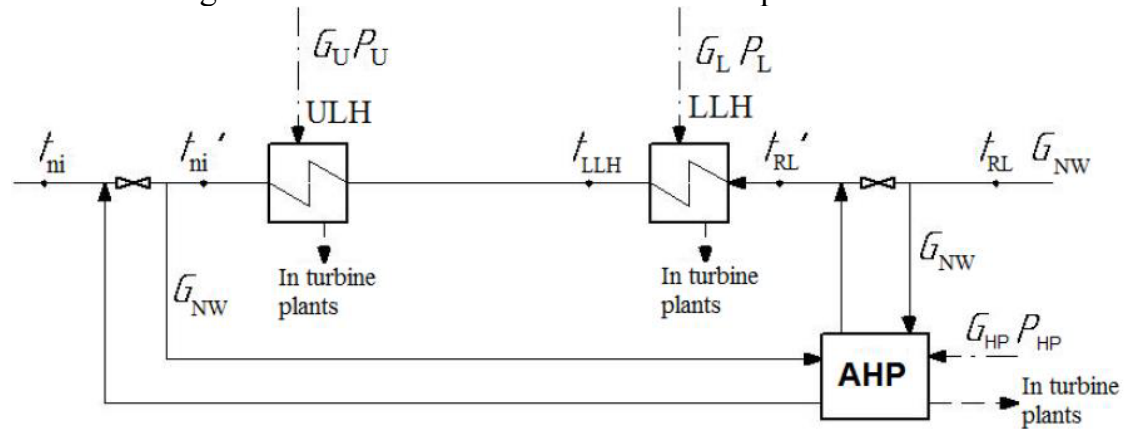

Fig. 2. Inclusion of absorption heat pumps into two-stage network installation of heating turbine scheme.

Initial data for design are presented in table 1. Design mode of heating turbine corresponds to equal heating of delivery water. It is close to the temperature of inclusion of Peak Water Boiler and it was accepted as equal to $t_{a a i r}=-15$ for Tomsk. The design shows that at minimal ambient air temperature a share of heating in the lower stage of network installation increases to $70 \%$ of overall heating of delivery water in lower line heater and upper line heater.

Table 1. Initial data for the task.

\begin{tabular}{|c|c|}
\hline Specifications & Value \\
\hline \multicolumn{2}{|l|}{ Common specifications for all modes } \\
\hline Turbine plant prototype & $\mathrm{T}-110-130$ \\
\hline Heat supply system temperature chart $\mathrm{t}_{\mathrm{h} h} / \mathrm{t}_{\mathrm{rl}},{ }^{\circ} \mathrm{C}$ & $150 / 70$ \\
\hline Extraction factor $\alpha_{\text {heat power plant }}$ & 0.6 \\
\hline Minimum design temperature of ambient air $\mathrm{t}_{\text {aair }},{ }^{\circ} \mathrm{C}$ & -40 \\
\hline Thermal capacity of system $\mathrm{Q}_{\mathrm{t}}, \mathrm{MW}$ & 200 \\
\hline Working vapor pressure $\mathrm{P}_{0}, \mathrm{MPa}$ & 13 \\
\hline Working vapor temperature $\mathrm{t}_{0},{ }^{\circ} \mathrm{C}$ & 540 \\
\hline Efficiency ratio of turbine $\eta_{o i}$ & 0.87 \\
\hline Product of mechanical efficiency and generation efficiency $\eta_{\mathrm{m}} * \eta_{\mathrm{g}}$ & 0.995 \\
\hline \multicolumn{2}{|l|}{ Design mode $\left(\mathrm{t}_{\text {aair }}=-15^{\circ} \mathrm{C}\right)$} \\
\hline Temperature of delivery water behind network installation $\mathrm{t}_{\mathrm{ni}},{ }^{\circ} \mathrm{C}$ & 95 \\
\hline Return wire temperature $\mathrm{t}_{\mathrm{rw}}{ }^{\circ} \mathrm{C}$ & 47 \\
\hline
\end{tabular}




\begin{tabular}{|c|c|}
\hline Share of heating in the lower stage of network installation (NI) & 0.5 \\
\hline \multicolumn{2}{|c|}{$\begin{array}{l}\text { Minimal design ambient air temperature mode without absorption heat pumps } \\
\qquad\left(\mathrm{t}_{\text {aair }}=-40^{\circ} \mathrm{C}\right)\end{array}$} \\
\hline Temperature of delivery water behind network installation $\mathrm{t}_{\mathrm{n},},{ }^{\circ} \mathrm{C}$ & 118 \\
\hline Return wire temperature $\mathrm{t}_{\mathrm{rw}}{ }^{\circ} \mathrm{C}$ & 70 \\
\hline \multicolumn{2}{|l|}{$\begin{array}{l}\text { Minimal design ambient air temperature mode with absorption heat pumps } \\
\left(\mathrm{t}_{\text {aair }}=-40^{\circ} \mathrm{C}\right)\end{array}$} \\
\hline Delivery water temperature behind condenser of absorption heat pumps $\mathrm{t}_{\mathrm{ni}},{ }^{\circ} \mathrm{C}$ & 118 \\
\hline Return wire temperature $\mathrm{t}_{\mathrm{rw}}{ }^{\circ} \mathrm{C}$ & 70 \\
\hline Coefficient of performance of absorption heat pumps $\varphi$ & 1.7 \\
\hline Vapor pressure of selection on absorption heat pumps $P_{h}$ & 0.5 \\
\hline
\end{tabular}

\section{Analysis results}

Analysis results are presented in Table 2.

Table 2. Analysis results.

\begin{tabular}{|c|c|c|c|}
\hline \multirow[b]{2}{*}{ Specification } & \multicolumn{3}{|c|}{ Value } \\
\hline & $\begin{array}{c}95 / 47 \\
\text { without } \\
\text { absorption } \\
\text { heat pumps }\end{array}$ & $\begin{array}{c}118 / 70 \\
\text { without } \\
\text { absorption } \\
\text { heat pumps }\end{array}$ & $\begin{array}{c}118 / 70 \\
\text { with } \\
\text { absorption } \\
\text { heat pumps }\end{array}$ \\
\hline Delivery water discharge $\mathrm{G}_{\mathrm{dw}}, \mathrm{kg} / \mathrm{s}$ & \multicolumn{3}{|c|}{992.1} \\
\hline $\begin{array}{l}\text { Vapor pressure of selection on upper line } \\
\text { heater } \mathrm{P}_{\mathrm{u}}, \mathrm{MPa}\end{array}$ & 0.1065 & 0.2292 & 0.1065 \\
\hline $\begin{array}{l}\text { Vapor pressure of selection on lower line } \\
\text { heater } \mathrm{P}_{1}, \mathrm{MPa}\end{array}$ & 0.0422 & 0.1436 & 0.0635 \\
\hline $\begin{array}{l}\text { Vapor feed rate of selection on upper line } \\
\text { heater } G_{u}, \mathrm{~kg} / \mathrm{s}\end{array}$ & 47.07 & 28.15 & 27.19 \\
\hline $\begin{array}{l}\text { Vapor feed rate of selection on lower line } \\
\text { heater } G_{l}, \mathrm{~kg} / \mathrm{s}\end{array}$ & 47.38 & 65.8 & 41.45 \\
\hline $\begin{array}{l}\text { Vapor feed rate of selection on absorption } \\
\text { heat pumps } \mathrm{G}_{\mathrm{hp}}, \mathrm{kg} / \mathrm{s}\end{array}$ & - & - & 26.55 \\
\hline $\begin{array}{l}\text { Delivery water heating in condenser of } \\
\text { absorption heat pumps } \Delta \mathrm{t}_{\text {heat }},{ }^{\circ} \mathrm{C}\end{array}$ & - & - & 23 \\
\hline $\begin{array}{l}\text { Delivery water cooling in evaporator of } \\
\text { absorption heat pumps } \Delta \mathrm{t}_{\text {cool }},{ }^{\circ} \mathrm{C}\end{array}$ & - & - & 9.47 \\
\hline $\begin{array}{l}\text { Delivery water temperature behind network } \\
\text { installation } \mathrm{t}^{\prime}{ }_{\mathrm{ni}}^{\circ},{ }^{\circ} \mathrm{C}\end{array}$ & - & - & 95 \\
\hline $\begin{array}{l}\text { Delivery water temperature after evaporator of } \\
\text { absorption heat pumps } \mathrm{t}_{\mathrm{rw}}^{\prime},{ }^{\circ} \mathrm{C}\end{array}$ & - & - & 60.53 \\
\hline $\begin{array}{l}\text { Delivery water temperature of lower line } \\
\text { heater } \mathrm{t}_{\mathrm{llh}},{ }^{\circ} \mathrm{C}\end{array}$ & 71 & 103.6 & 81.14 \\
\hline Vapor feed rate on turbine $\mathrm{G}_{0}, \mathrm{~kg} / \mathrm{s}$ & 94.45 & 93.95 & 95.19 \\
\hline Generated electric power $\mathrm{N}_{\mathrm{e}}, \mathrm{MW}$ & 92.6 & 81.24 & 84.77 \\
\hline $\begin{array}{l}\text { Specific vapor consumption on turbine } \mathrm{d}_{0} \text {, } \\
\mathrm{kg} / \mathrm{MJ}\end{array}$ & 1.02 & 1.156 & 1.123 \\
\hline $\begin{array}{l}\text { Specific electric energy production on heat } \\
\text { consumption e }\end{array}$ & 0.463 & 0.406 & 0.424 \\
\hline
\end{tabular}

Design results of turbine plant efficiency at different modes of network installation are presented in fig. 3,4 . 


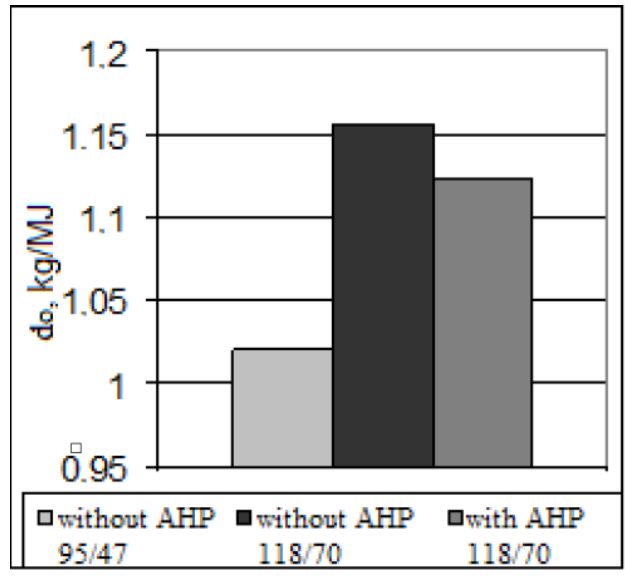

Fig. 3. Inclusion of specific vapor consumption on turbine for different modes of network installation efficiency.

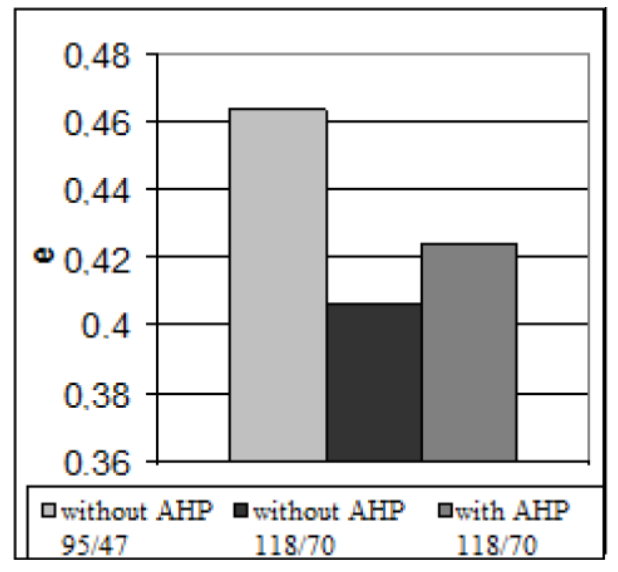

Fig. 4. Specific electric energy production at heat consumption for different modes of network installation efficiency.

\section{Conclusion}

To sum up:

○ Delivery water heating in lower and upper heaters of two-stage network installation during heating season greatly differs from equal one. During ambient air temperature decrease thermal load of lower heat extraction and share of water heating in lower line heater grows. During delivery water discharge decrease and increase of temperature in return line at other equal conditions inequality of heating increases.

- Use of absorption heat pumps in stage heating increase of delivery water scheme of stage heating delivery water at low temperatures of ambient air allows to decrease return wire temperature at the input into lower line heater and at the output of upper line heater and approximate off-design conditions of network installation to equal one.

- Efficiency of inclusion of absorption heat pumps into two-stage network installation scheme of heating turbine without interstage interval with initial characteristics $\mathrm{P}_{0}=13 \mathrm{MPa}, \mathrm{t}_{0}=550{ }^{\circ} \mathrm{C}$ for mode with minimum temperature of ambient air is evaluated by increase of electric energy generation at heat consumption $2-3 \%$ in reference to initial model.

\section{References}

1. D.P. Elizarov, Je.I. Tazhiev, Jelektricheskie stancii 2, (1994) [in Russian]

2. O.Ju. Romashova, O.R. Gabidullin, Jenergetika: Jekologija, nadezhnost', bezopasnost'. Materialy dokladov devjatoj Vserossijskoj nauchno-tehnicheskoj konferencii - Tomsk, TPU, 3-5.12.2003 239 (2003) [in Russian]

3. O.Ju. Romashova, O.R. Gabidullin, Jenergetika: Jekologija, nadezhnost', bezopasnost'. Materialy dokladov devjatoj Vserossijskoj nauchno-tehnicheskoj konferencii - Tomsk, TPU, 8-10.12.2004 222 (2003) [in Russian]

4. D. Luzhkovoy, O. Romashova, A. Tubolev, Y. Kobenko, E. Riabova, MATEC Web Conf. 92, 01054 (2017) 